\title{
Kelola
}

\section{Evaluasi Implementasi Kebijakan Pendidikan Inklusi}

\author{
Sasadara Wahyu Lukitasari \\ Magister Manajemen Pendidikan \\ Universitas Kristen Satya Wacana \\ sasadara@gmail.com \\ Bambang Suteng Sulasmono \\ Magister Manajemen Pendidikan \\ Universitas Kristen Satya Wacana \\ bambang.sulasmono@staff.uksw.edu

\section{Ade Iriani} \\ Magister Manajemen Pendidikan \\ Universitas Kristen Satya Wacana \\ ade.iriani@staff.uksw.edu
}

\begin{abstract}
The purpose of this study is to evaluate the implementation of inclusive education policy in Salatiga City. This study used a qualitative evaluative approach to the research subject of Dinas Pendidikan and inclusion schools in Salatiga. In-depth interviews, document studies, and observations were used to collect data and then analyzed using an Edwards III implementation model that looked at communication, resource, disposition, and bureaucratic structure. The results showed that the implementation of inclusive education policy in Salatiga is considered good, that is the achievement of $65 \%$. Communication is an aspect that requires a lot of improvement, as well as the bureaucratic structure and disposition that is still not a good implementation. While the best aspect is the resources. The impact of this policy is evident from the increasing number of students in regular schools from year to year and the reduced discrimination experienced by $A B K$ students by peers, teachers and the community.
\end{abstract}

Keywords: evaluation, inclusive education, policy implementation

\section{Article Info}




\section{PENDAHULUAN}

Model pendidikan inklusi merupakan sebuah alternatif yang ditawarkan oleh pemerintah untuk melayani Anak Berkebutuhan Khusus (ABK). Pendidikan ini bukan digunakan untuk menggantikan pendidikan segregasi dalam konteks pendidikan luar biasa di Indonesia yang selama ini terlayani dengan Sekolah Luar Biasa (SLB) dan Sekolah Terpadu. Sistem ini memungkinkan ABK bersekolah di sekolah reguler sehingga membuka akses pendidikan yang lebih luas, bagi para ABK. Sekolah inklusi dimaksudkan untuk memperpendek akses pendidikan bagi ABK yang biasanya bertempat tinggal jauh dari pusat kota dimana terdapat SLB sehingga mereka tidak mengalami putus sekolah. Subagya dalam Haryono (2015:122123) menyebutkan bahwa terdapat 26.568 (79,37\%) ABK di Jawa Tengah belum sekolah. Para ABK ini tidak mendapatkan pendidikan karena beberapa alasan, seperti jauhnya tempat tinggal ABK dari sekolah khusus, ABK ditolak bersekolah di sekolah terdekat, banyak orang tua $\mathrm{ABK}$ menyembunyikan ketunaan anaknya dan rendahnya motivasi orang tua untuk menyekolahkan anak mereka yang berkebutuhan khusus.

Persoalan-persoalan tersebut di atas barang tentu tidak dapat diselesaikan sendiri oleh masyarakat, sehingga diperlukan penanganan oleh pemerintah melalui kebijakan publik. Kebijakan publik dapat dirumuskan sebagai sebuah aksi yang dilakukan oleh aktor politik sebagai strategi untuk mengatasi masalah publik dengan mempertimbangkan hambatan dan potensi yang ada guna mencapai tujuan yang dicita-citakan. Alur pembuatan kebijakan publik dimulai dari adanya isu kebijakan, perumusan kebijakan, implementasi kebijakan dan evaluasi kebijakan. Nugroho (2009: 145) menambahkan bahwa kegiatan setelah evaluasi kebijakan diperlukan lagi revisi kebijakan untuk merumuskan kembali kebijakan.

Tahap implementasi kebijakan adalah tahap yang sangat penting dalam proses kebijakan. Kebijakan yang sudah terencana dengan sempurna bila kurang bagus proses implementasinya oleh para pelaksana maka kebijakan itu akan menemui kegagalan. Wahab (2015: 132-133) menjelaskan bahwa menurut sudut pandang teori siklikal (Cyclical Theory) implementasi kebijakan merupakan bagian dari tahapan dalam proses kebijakan berupa bentuk produk hukum, dan aktivitas lanjutan sesudah diberlakukannya produk hukum tersebut. Dapat diartikan bahwa implementasi kebijakan adalah tindakan saling kerja sama antar pemerintah dengan pihak swasta untuk melaksanakan kebijakan yang telah ditetapkan pada tahap sebelumnya guna mencapai tujuan yang ditetapkan.

Ketika kebijakan tidak dijalankan secara baik, maka akan timbul kesenjangan implementasi (implementation gap) yang diartikan sebagai "perbedaan antara hukum yang tertulis dengan prakteknya di lapangan". Biasanya implementation gap ini terlihat dan sering dirasakan pada level bawah (Nakagaki, 2013:1). Penyebab adanya implementation gap dapat berasal dari faktor politik, ekonomi, dan sosial budaya. Untuk mengatasi implementation gap dibutuhkan pendekatan yang berfokus pada kualitas kebijakan dan memastikan bahwa kebijakan tersebut benarbenar sesuai dengan kebutuhan sasaran (masyarakat). Pemerintah, sektor swasta dan masyarakat harus bekerja sama untuk mengatasi implementation gap ini.

George Edward III (1980) menyatakan bahwa jika implementasi kebijakan publik kurang diberi perhatian, maka implementasi tidak efektif sehingga kebijakan itu tidak akan berhasil dijalankan. Untuk menjamin keberhasilan implementasi kebijakan perlu diperhatikan empat hal, yaitu komunikasi, sumber daya, disposisi, dan struktur birokrasi.

Komunikasi. Komunikasi kebijakan adalah proses penyampaian informasi tentang kebijakan dari pembuat kepada pelaksana kebijakan (implementor) (Widodo, 2011:97). Hal ini penting dilakukan supaya pelaksana kebijakan dapat memahami hakikat kebijakan, isi, tujuan, arah, cara pelaksanaan, batasan, evaluasi, kelompok sasaran dan lain sebagainya 
sehingga dapat mempersiapkan pelaksanaan kebijakan agar proses implementasi berjalan lancar dan efektif. Faktor-faktor yang penting dalam penyampaian informasi, adalah transmisi (cara penyampaian), clarity (kejelasan informasi), dan consistency (konsistensi informasi).

Sumber Daya. Sumber daya berkaitan dengan ada tidaknya sumber daya pendukung, khususnya kualitas sumber daya manusia untuk menjalankan kebijakan secara efektif. Widodo (2011:98) menyebutkan bahwa walaupun aturan yang dibuat sudah jelas dan akurat, namun implementasi tidak akan efektif jika sumber daya pelaksana kebijakan kurang bertanggung-jawab dalam melaksanakan kebijakan yang bersangkutan. Potensi sumber daya yang tinggi akan membuat implementasi berjalan dengan baik, sebaliknya, rendahnya potensi sumber daya akan menjadi penyebab gagalnya implementasi kebijakan. Sumber daya tersebut terdiri dari sumber daya manusia, anggaran, fasilitas, informasi, dan kewenangan.

Disposisi. Edward (1980:89) mendefinisikan disposisi sebagai pembawaan, kepribadian, pandangan, ideologi pelaksana kebijakan publik. Kemauan dan dedikasi serta karakteristik para implementor kebijakan untuk melaksanakan kebijakan sangat penting untuk keberlangsungan implementasi kebijakan.

Struktur birokrasi. Struktur birokrasi disini adalah semua instrumen organisasi secara menyeluruh dan terstruktur. Terdapat dua aspek struktur organisasi ini, yaitu mekanisme dan struktur birokrasi. Mekanisme biasanya dibuat dalam Standard Operational Procedure(SOP) yang merupakan pedoman langkah-langkah berupa keseragaman pola dalam pelaksanaan implementasi kebijakan supaya tidak melenceng dari yang sudah ditetapkan. Aspek penting lain dari struktur birokrasi adalah ada atau tidaknya fragmentasi atau perpecahan di kalangan birokrasi pelaksana kebijakan Fragmentasi di lingkungan birokrasi pelaksana kebijakan akan membuat permasalahan dalam implementasi.

Pendidikan Inklusi. Konsep inklusi dijelaskan oleh Smith (2006: 43) sebagai pembauran anak-anak berkelainan ke dalam program sekolah regular. Selain itu inklusi dapat diartikan sebagai akseptasi siswa dengan keterbatasan dalam kurikulum, lingkungan, interaksi sosial dan konsep diri sekolah. Hal yang senada diungkapkan Valle \& Connor dalam Santrock (2014:226) yang menyatakan bahwa inklusi berarti memberi pendidikan anak dengan pendidikan khusus secara penuh-waktu di kelas reguler. Namun dia memberi catatan bahwa hal tersebut tergantung pada tingkat disabilitasnya. Sedangkan dalam Permendiknas No. 70 Tahun 2009 pasal 1 diterangkan bahwa pendidikan inklusi adalah "sistem penyelenggaraan pendidikan yang memberikan kesempatan kepada semua peserta didik yang memiliki kelainan dan memiliki potensi kecerdasan dan/atau bakat istimewa untuk mengikuti pendidikan atau pembelajaran dalam satu lingkungan pendidikan secara bersamasama dengan peserta didik pada umumnya." Siswa dengan kelainan fisik, emosional, mental, dan sosial atau memiliki potensi kecerdasan dan/atau bakat istimewa memiliki hak untuk ikut mengenyam pendidikan secara inklusi pada satu sekolah sesuai kebutuhan dan kemampuannya. Sedangkan yang dimaksud kelainan itu adalah tunanetra, tunarungu, tunawicara, tunagrahita, tunadaksa, tunalaras, berkesulitan belajar, lamban belajar, autis, memiliki gangguan motorik, menjadi korban penyalahgunaan narkoba, obat terlarang, dan zat adiktif lainnya, memiliki kelainan lainnya, tunaganda. Dari pengertian diatas, penulis berpendapat bahwa pendidikan inklusi adalah layanan pendidikan untuk anak berkebutuhan khusus dengan keterbatasan fisik, mental, berkemampuan istimewa, korban narkoba, minoritas, dan keterbatasan belajar lainnya yang menyatu dengan sekolah reguler di dekat tempat tinggalnya.

Inklusi diperlukan agar terjadi pemerataan pendidikan dengan memperpendek akses pendidikan ke pendidikan khusus dan memenuhi hak pendidikan anak. Dengan ini dapat membantu siswa dengan pemenuhan pendidikan yang berkualitas, membantu mengoptimalkan potensi mereka sehingga dapat berkontribusi terhadap komunitas dan masyarakat. Inklusi juga dimaksudkan untuk mempromosikan perubahan dan nilai-nilai sosial dan mengurangi diskriminasi dalam 
masyarakat. Dengan menempatkan siswa ABK setara dengan siswa normal, masyarakat diharapkan dapat melihat perbedaan yang ada sebagai keanekaragaman dalam masyarakat (Walker, th:15)

Mangunsong (2009:4) menjelaskan bahwa Anak Berkebutuhan Khusus atau Anak Luar Biasa adalah anak yang berbeda dibanding anak normal kebanyakan dalam hal: ciri-ciri mental, kemampuan-kemampuan sensorik, fisik dan neuro-maskular, perilaku sosial dan emosional, kemampuan berkomunikasi, maupun kombinasi dua atau lebih dari hal-hal diatas; selama mereka membutuhkan modifikasi tugas sekolah, metode belajar atau pelayanan terkait lainnya, bertujuan untuk pengembangan potensi atau kapasitasnya secara maksimal. Diretcgov merujuk ABK kepada anak yang memiliki kesulitan belajar yang membuatnya lebih sulit untuk belajar atau mengakses pendidikan dibandingkan kebanyakan anak seusianya. Menurut penulis, ABK adalah anak-anak yang memiliki keterbatasan dalam hal fisik maupun mental sehingga mengalami kesulitan belajar atau mengakses pendidikan dibandingkan anak lainnya.

Disabilitas sangat erat kaitannya dengan kemiskinan. Terdapat siklus yang terus berulang. Orang dengan disabilitas memiliki kemungkinan untuk berada di golongan ekonomi lemah (Walker, tth:13). Oleh karena ABK atau difabel harus memiliki pendidikan yang layak dan berkualitas untuk mengurangi tingkat kemiskinan dan meningkatkan taraf hidup mereka.

Selain anak berbekutuhan khusus pendidikan inklusi juga melayani anak Cerdas Istimewa dan Bakat Istimewa (CIBI). Munandar dalam Wulan (2011:260) menjelaskan bahwa anak CIBI membutuhkan penanganan khusus dalam pendidikan karena beberapa karakteristik yang dimiliki anak-anak tersebut membuat mereka berbeda dengan siswa lain. Sehingga untuk mengembangkan potensinya secara optimal, dibutuhkan kurikulum dan metode yang berbeda dalam pengajarannya sesuai minat, dan bakat mereka.
Supaya tidak dianggap "aneh" atau under achiever (prestasi tidak sesuai dengan kemampuannya) maka dibutuhkan pelayanan yang berbeda dengan sekolah reguler. Hertzog dalam Santrock (2014:232-233) mengusulkan beberapa program untuk menangani anak berbakat, yaitu kelas khusus, percepatan (akselerasi) dan pengayaan dalam pengaturan kelas reguler, mentor dan program magang serta kerja/studi dan/atau program layanan.

Kebijakan Pendidikan Inklusi di Indonesia. Indonesia mulai mengupayakan pendidikan inklusi sejak dikeluarkannya Surat Edaran Dirjen Dikdasmen Depdiknas No.380/C.C6/MN/2003 pada 20 Januari 2003 kemudian diperkuat dengan dikeluarkannya Permendiknas No. 70 tahun 2009 tentang Pendidikan Inklusi bagi peserta didik yang memiliki kelainan dan memiliki potensi kecerdasan dan/atau bakat istimewa. Hal ini memang sejalan dengan hasil kesepakatan Konferensi Dunia di Salamanca pada tahun 1994 dan Deklarasi Dakar tahun 2000 yang berupaya mengakomodasikebutu han dasar masya-rakat tentang pendidikan untuk semua (Education for All) tanpa memandang ras, agama dan potensi peserta didik.

Sambutan masyarakat terhadap model ini pun cukup tinggi ditandai dengan jumlah sekolah penyelenggara inklusi dan siswanya yang meningkat secara signifikan. Walaupun begitu, implementasi di lapangan masih jauh dari apa yang diharapkan. Hal tersebut terutama dikarenakan kurangnya komitmen dan dukungan pemerintah.

Penyelenggaraan pendidikan inklusi di Kota Salatiga telah berjalan sejak 2010 di sejumlah sekolah. Kebijakan ini tertuang dalam Perwali No. 11 Tahun 2013 tentang Penyelenggaraan Pendidikan Inklusi. Adanya kebijakan ini membuat semua sekolah dari tingkat SD sampai SMA wajib menerima anakanak berkebutuhan khusus (Salatiga Miliki Unit Layanan Konsultasi Pendidikan, 2013). Supriyanto (2013:8-9) menjelaskan bahwa Salatiga ditunjuk sebagai Kota inklusi sejak tahun 2012. Pemerintah telah menunjuk 
beberapa sekolah untuk menjadi pilot project penyelenggaraan inklusi dengan pola menjadikan SLB sebagai pusat sumber belajar. Piloting melibatkan 6 SMP dan 6 SD untuk kategori inklusi dan CIBI. Data yang didapat dari Dinas Pendidikan Kota Salatiga tahun 2015 terdapat 431 siswa ABK yang bersekolah di 15 sekolah regular jenjang SD dan SMP dengan program inklusi, dan 213 siswa dengan program CIBI (Cerdas Bakat Istimewa) di 5 sekolah di jenjang yang sama.

Hasil wawancara dengan Kepala Sekolah SDN Blotongan 3 pada bulan Mei 2016 dan Koordinator Program Akselerasi di SMP 2 pada bulan yang sama menunjukkan bahwa terdapat beberapa permasalahan yang terjadi pada implementasi program inklusi. Pemerintah seperti kurang serius menangani sekolah inklusi di Salatiga ini, mulai dari pendanaan, Guru Pendamping Khusus dan lain-lain. Program inklusi di SMP 2 untuk kategori Cerdas Istimewa dihentikan karena tidak adanya dana dari pemerintah. Selain itu banyak sekolah inklusi yang tidak berjalan sebagaimana mestinya karena tidak adanya Guru Pendamping Khusus seperti yang dipersyaratkan. Sehingga dipertanyakan masihkah Kota Salatiga pantas disebut sebagai Kota Inklusi, dan efektifkah model inklusi diterapkan untuk menjawab kebutuhan pendidikan anak berkebutuhan khusus.

Berdasarkan latar belakang di atas, maka peneliti tertarik untuk mengevaluasi implementasi kebijakan pendidikan inklusi di Kota Salatiga dengan rumusan masalah "Bagaimana implementasi program inklusi di Kota Salatiga dilihat dari komunikasi, sumber daya, struktur birokrasi dan disposisinya?"

\section{METODE PENELITIAN}

Penelitian ini merupakan penelitian evaluatif. Evaluasi implementasi kebijakan ini menggunakan model evaluasi kebijakan sistematis terhadap faktor komunikasi, sumber daya, disposisi, dan struktur birokrasi sebgaiman dimaksud dalam model implementasi Edwards III. Penelitian dilakukan di beberapa sekolah yang ditunjuk sebagai pilot project program inklusi di Kota Salatiga di tingkat pendidikan dasar, yaitu SD dan SMP. Subyek penelitian ini adalah Dinas Pendidikan Kota Salatiga, serta sekolah-sekolah di tingkat SD dan SMP di Salatiga yang menerapkan program inklusi. Data penelitian diperoleh melalui wawancara mendalam, studi dokumen, kuesioner dan observasi. Teknis validasi yang digunakan dalam penelitian ini adalah triangulasi sumber dan triangulasi teknik. Dalam teknik triangulasi sumber, peneliti mengecek kebenaran data dari beragam sumber. Data-data tersebut dideskripsikan, dikategorikan, dicari pandangan yang sama dan berbeda serta yang lebih spesifik. Setelah dianalisis dan ditarik kesimpulan, sumber data diminta kesepakatan (member check) tentang data tersebut.

\section{HASIL DAN PEMBAHASAN}

Pencanangan program inklusi di Salatiga dilaksanakan pada tanggal 12 Desember 2012. Sejak itu Kota Salatiga mulai melaksanakan pendidikan inklusi di beberapa sekolah yang ditunjuk sebagai pilot project-nya. Hasil penilaian terhadap implementasi kebijakan program inklusi dapat dilihat di Tabel 1.1. Secara keseluruhan implementasi kebijakan program inklusi ini masuk dalam kategori baik dengan pencapaian 65\%. Komunikasi mendapatkan nilai yang paling rendah dibandingkan aspek lain, sedangkan sumber daya merupakan aspek yang paling bagus. 
Tabel 1.1

Hasil Evaluasi Implementasi Kebijakan Program Inklusi Kota Salatiga

\begin{tabular}{|l|c|c|}
\hline \multicolumn{1}{c}{ Aspek } & Nilai /Nilai total tiap aspek & $\begin{array}{c}\text { Capaian } \\
\text { (dalam \%) }\end{array}$ \\
\hline Tujuan Program & $3 / 4$ & $75 \%$ \\
\hline Komunikasi & $11 / 20$ & $55 \%$ \\
\hline Struktur Birokrasi & $5 / 8$ & $63 \%$ \\
\hline Sumber daya & $14 / 20$ & $70 \%$ \\
\hline Disposisi & $5 / 8$ & $63 \%$ \\
\hline Dampak & $9 / 12$ & $75 \%$ \\
\hline Total & $\mathbf{4 7 / 7 2}$ & $\mathbf{6 5 \%}$ \\
\hline
\end{tabular}

Sumber: Data penelitian diolah

Dari segi komunikasi data evaluasi menunjukkan adanya permasalahan di hampir semua aspek komunikasi karena empat dari lima aspek yang ada menunjukkan penilaian yang kurang baik. Aspek tersebut antara lain dalam hal saluran komunikasi, kejelasan informasi yang diterima, kelengkapan informasi yang diterima kelompok sasaran, dan konsistensi informasi kebijakan. Penilaian yang baik terdapat pada aspek adanya persepsi yang yang sama antara pembuat kebijakan dan pelaksana kebijakan mengenai kebijakan yang dijalankan.

Komunikasi berupa sosialisasi yang dilakukan satu arah kepada pelaksana kebijakan dan kelompok sasaran dilakukan dengan berbagai cara, antara lain rapat dan sosialisasi formal ke sekolah-sekolah, seminar, pameran, klinik konseling, media massa, rapat orang tua, brosur dan formulir pendaftaran. Walaupun begitu penyampaian informasi tentang kebijakan program inklusi kepada implementator dan kelompok sasaran masih dirasa kurang sehingga banyak terjadi kekurang pahaman dan ketidaktahuan tentang program ini. Masyarakat umum masih banyak yang belum mengetahui mengenai program ini selain dari pihak sekolah sendiri. Hal ini ditandai dengan masih sedikitnya jenis ketunaan siswa di sekolah reguler. Masih banyak orang tua siswa yang belum mengetahui jika anak dengan disabilitas bisa bersekolah di sekolah reguler bersama teman yang normal.

Sementara itu dalam hal clarity (kejelasan), kebijakan ini dinilai masih kurang baik. Walaupun kebijakan ini mudah dipahami dan kontroversi mengenai kebijakan ini sudah mereda, namun juklak dan juknis yang ada dirasa masih kurang jelas bagi beberapa pelaksana kebijakan. Informasi yang diterima pun juga kurang jelas. Sebelumnya pelatihan yang diberikan dirasa kurang optimal sehingga pemahaman GPK dirasa masih kurang dalam menyelenggarakan pendidikan inklusi.

Dari sisi struktur birokrasi, implementasi kebijakan pendidikan inklusi di aras kota dikelola oleh sebuah Kelompok Kerja (Pokja). Para pihak yang terlibat dalam Pokja antara lain Dinas Pendidikan, Pemuda dan Olahraga, Kementrian Agama, Bappeda, SLB, Sekretariat Daerah dan dari universitas, antara lain Universitas Negeri Semarang, Universitas Kristen Satya Wacana, Sekolah Tinggi Agama Islam Negeri Salatiga. Di samping itu Pokja Inklusi Kota Salatiga kemudian menjadikan UPTD sebagai pusat sumber sendiri yang berupa Klinik Konseling, dan bukan bekerjasama dengan SLB sebagai pusat sumber.

Dalam kenyataan belum semua pihak terlibat aktif dalam implementasi kebijakan. Porsi utama dalam Pokja adalah pada Dinas Pendidikan Pemuda dan Olahraga. Adanya perbedaan pandangan antara SLB, Pokja Inklusi dalam memandang Pusat Belajar dan peran lembaga masing-masing, serta belum samanya pandangan antara Kementerian Agama dan Pokja inklusif dalam melihat keterlibatan MI dan MTs untuk menjalankan program inklusi ini memperlihatkan adanya miskomunikasi yang terjadi antar lembaga 
tersebut. Bisa juga dikatakan ini adalah sebuah fragmentasi diantara pelaksana kebijakan.

SOP program ini adalah Pedoman Umum Penyelenggaraan Pendidikan Inklusi yang dikeluarkan oleh Direktorat PPK-LK Pendidikan Dasar Kementerian Pendidikan Dan Kebudayaan. Pedoman inilah yang kemudian digunakan sebagai panduan sekolahsekolah penyelenggara inklusi dalam penyelenggaraan inklusi di sekolah masingmasing. Hampir semua sekolah sudah menerima pedoman ini dan melaksanakan seperti petunjuk di dalam buku tersebut. Dalam panduan tersebut lebih banyak penjelasan yang hanya dapat diterapkan pada sekolah/kelas inklusi dengan siswa ABK yang memiliki keterlambatan belajar. Sedangkan panduan untuk siswa dengan kecerdasan dan keberbakatan istimewa masih dirasa kurang.

Dari sisi sumber daya, evaluasi menunjukkan bahwa secara keseluruhan sumber daya implementasi kebijakan termasuk kategori baik yang ditandai dengan adanya penilaian baik terhadap empat dari lima indikator penilaian. Indikator yang memperoleh nilai baik adalah jumlah SDM, fasilitas pendukung, relevansi informasi, dan anggaran untuk menjalankan program/kebijakan. Penilaian yang kurang baik terdapat pada kualitas SDM pelaksana kebijakan ini.

Sumber daya yang diperlukan dalam implementasi kebijakan antara lain sumber daya manusia, fasilitas, pendanaan dan informasi. Dari segi kuantitas, jumlah GPK di sekolah-sekolah penyelengara inklusi sudah memenuhi standar nasional, yaitu minimal 1 (satu) orang GPK per sekolah. Namun Kota Salatiga memiliki standar sendiri, yaitu 1 sekolah harus terdapat 2 (dua) orang GPK, sehingga jumlah GPK di Salatiga sudah melebihi standar yang ditetapkan. Hanya saja dari segi kualitas, SDM pelaksana program ini dinilai kurang baik. Banyak GPK yang belum melaksanakan tupoksi secara optimal. Beberapa sebabnya antara lain kurangnya pengetahuan tentang tupoksi GPK, dan terbatasnya waktu GPK untuk mengajar.
Sumber daya berupa informasi dirasa masih kurang lengkap di awal-awal masa pencanangan pendidikan inklusi di tahun 2012 karena masih belum tersosialisasinya program ini secara meluas, serta pelatihan dan sosialisasi yang kurang masif. Namun dengan adanya pelatihan-pelatihan dan sosialisasi yang lebih masif dilakukan pada akhir tahun 2016, informasi yang diterima oleh pelaksana kebijakan mengenai apa yang harus dilakukan dan bagaimana melakukannya semakin jelas dan lengkap. Sayangnya ini belum dibarengi dengan adanya pusat data dan informasi (Padati) ABK yang valid dan reliable untuk mendukung kerja pelaksana kebijakan dan masyarakat pada umumnya.

Dari segi anggaran, pemenuhan biaya untuk menjalankan program inklusi di Kota Salatiga ini sudah baik. Ini dibuktikan dengan adanya anggaran yang dialokasikan dari pemerintah Kota Salatiga mulai tahun anggaran 2014 sampai sekarang. Sebelum itu, anggaran dari APBD berasal dari Provinsi Jawa Tengah, dan APBN melalui Dirjen PPLK, walaupun anggaran ini tidak rutin turun setiap tahunnya. Belum terdapat partisipasi masyarakat berupa bantuan sosial.

Dari sisi disposisi pelaksana kebijakan, komitmen pelaksana kebijakan untuk melaksanakan program ini dinilai baik, walau masih dirasa adanya permasalahan dalam hal penghargaan bagi pelaksana kebijakan.

Baiknya dedikasi dan kemauan pelaksana kebijakan ditandai oleh adanya komitmen sekolah untuk menyelenggarakan program inklusi serta kesediaan para guru melaksanakan tupoksinya sebagai GPK. Adanya komitmen sekolah dalam menyelenggarakan pendidikan inklusi juga dapat dilihat dengan tidak adanya sekolah yang menolak masuknya siswa yang berkebutuhan khusus di sekolah mereka. Walaupun beberapa sekolah menerapkan kriteria jenis ketunaan yang bisa diterima, yaitu kategori ringan dan tidak menganggu teman lainnya. Sayangnya komitmen ini belum dibarengi dengan lingkungan sekolah ramah ABK, terutama dalam hal penyediaan fasilitas yang ramah terhadap $\mathrm{ABK}$. 
Disposisi yang baik biasanya ditunjang dengan adanya penghargaan yang diberikan kepada pelaksana kebijakan. Sayangnya hal ini dinilai masih kurang berjalan dengan baik. Guru (khususnya yang berstatus sebagai Pegawai Negeri Sipil) yang merangkap sebagai GPK belum mendapatkan angka kredit yang berguna untuk kenaikan jabatan/golongan. Selain itu selama program berjalan selama 4 tahun, belum ada penghargaan yang diberikan kepada pelaksana kebijakan yang berperan penting dalam perkembangan pendidikan inklusi di Kota Salatiga.

\section{Pembahasan}

\section{Komunikasi dalam Implementasi Kebijakan Pendidikan Inklusi di Kota Salatiga}

Hasil penelitian menunjukkan bahwa pada sisi komunikasi aspek transmisi dinilai kurang baik, aspek kejelasan juga kurang baik, sedang aspek konsistensi dinilai cukup baik. Oleh karena itu dapat dipahami jika masih terjadi kesenjangan implementasi kebijakan pendidikan inklusi di kota Salatiga. Hal ini dapat dipahami dari teori Edward III (Winarno, 2011: 181) yang menyatakan bahwa “ ...semakin cermat keputusan-keputusan dan perintah-perintah pelaksanaan diteruskan kepada mereka yang harus melaksanakan-nya, maka makin tinggi pula probabilitas keputusankeputusan kebijakan dan perintah perintah pelaksanaan tersebut dilaksanakan"

Sedang keengganan orang tua untuk menyekolahkan anak berkebutuhan khususnya ke sekolah dapat dijelaskan melalui pendapat Nagakaki (2013:4) yang menyatakan bahwa salah satu penyebab adanya implementation gap adalah faktor sosial budaya. Adanya warisan budaya yang tertanan selama beberapa generasi menyebabkan stereotipe budaya. Dengan ini paradigma masyarakat akan susah dirubah dengan sesuatu yang baru. Begitu halnya dengan pendidikan segregatif yang sudah lebih dari seabad ada di Indonesia. Sekolah untuk siswa ABK dimulai sejak jaman sebelum kemerdekaan pada tahun 1901 di Bandung untuk para tunanetra, sedangkan setelah kemerdekaan pendidikan untuk ABK dijamin oleh UU Pendidikan No 12 tahun 1954 tentang pendidikan dan pengajaran luar biasa. Adanya UU tersebut muncullah SLB sebagai layanan pendidikan bagi penyandang disabilitas (Sunanto:6). Untuk itulah diperlukan suatu terobosan untuk memperkenalkan konsep pendidikan inklusif ke masyarakat sehingga dapat merubah paradigma masyarakat bahwa ABK tidak harus bersekolah di SLB.

Di samping itu forum untuk orang tua atau masyarakat juga belum terbentuk di Kota Salatiga. Padahal forum ini sangat penting keberadaannya sdan bahkan telah dituangkan dalam Progam Pendidikan Inklusif Kota Salatiga di tahun ketiga (2014) yaitu "terbentuknya forum dan atau asosiasi orang tua dan pemangku kepentingan pendidikan inklusi". Memang hal semacam itu tidak hanya terjadi di Kota Salatiga saja. Penelitian oleh Haryono (2015:124) yang menjangkau Provinsi Jawa Tengah juga menemukan hal yang serupa, yaitu banyak sekolah yang belum melibatkan masyarakat dalam penyelengga-raan pendidikan inklusif. Padahal komunikasi dan kerjasama dengan masyarakat dan beberapa stakeholder sangat penting bagi pendidikan ABK agar mendapat pendidikan yang berkualitas dalam lingkungan yang inklusif dan ramah terhadap pembelajaran (LIRP).

Nagakaki (2013:7) menyatakan bahwa peran aktif masyarakat dapat mengurangi adanya kesenjangan implementasi, salah satu yang bisa dilakukan adalah bekerjasama dengan organisasi yang lebih besar dan berpengalaman. Keterlibatan keluarga dan anggota masyarakat lain sangat penting dalam implementasi pendidikan inklusif. Kerjasama bisa dilakukan dengan kemitraan antar Dinas, misalnya Dinas Sosial, Dinas Tenaga Kerja, dan Dinas Kesehatan. Selain antar dinas, kemitraan juga harus menjangkau masyarakat, orang tua, para pengusaha, tokoh masyarakat yang memiliki kepentingan. Hal ini dapat dilakukan secara individual atau level organisasi, baik organisasi kemasyarakatan yang dibentuk oleh Pemerintah (GO) maupun non pemerintah (NGO) (Wasliman, 2009:137138). 


\section{Struktur Birokrasi dalam Implementasi Kebijakan Pendidikan Inklusi di Kota Salatiga}

Menurut Nagakaki (2013: 2) salah satu penyebab adanya implementation gap adalah faktor politik. Dalam kasus Kota Salatiga, struktur birokrasi merupakan salah satu penyebab adanya implementation gap dalam implementasi kebijakan pendidikan inklusi. Terdapat ketidakjelasan atau tanggung jawab yang tumpang tindih pada struktur birokrasi. Pokja yang melibatkan beberapa instansi belum semua terlibat dalam pelaksanaan program. Porsi utama dalam Pokja adalah pada Dinas Pendidikan Pemuda dan Olahraga, namun dinas lain yang terkait juga harusnya bisa dilibatkan karena peran dinas lain juga semestinya tidak kecil. SLB dapat melakukan tugas di bidang pendidikan dan pelatihan bagi para GPK yang berlatar belakang bukan PLB (Pendidikan Luar Biasa) sehingga para GPK di SD reguler mendapatkan wawasan bagaimana sebenarnya menangani siswa ABK. Selain itu peran Kementerian Agama yang membawahi MI dan MTs semestinya juga tidak kecil. Tercatat pada tahun 2010/2011 terdapat 12 MI dan 3 MTs. Jika program inklusi juga diterapkan di dua lembaga tadi, siswa-siswa ABK pastilah tertangani dengan lebih baik. Selain itu instansi ini bisa mendapatkan fasilitas berupa dana, atau bantuan pendidikan bagi guru untuk penanganan siswa ABK. Selain itu birokrasi dimana pendidikan dasar yang meliputi SD dan SMP merupakan wewenang Pemerintah Kota, sementara SMA/SMK berada di level Provinsi membuat sekolah inklusi di tingkat sekolah menengah atas belum dapat dilaksanakan.

Pusat sumber sangat penting peranannya sebagai sistem pendukung implementasi pendidikan inklusif. Menurut Saepul (2013, 3033), pusat sumber adalah "suatu unit atau institusi yang berfungsi memberikan pelayanan pendukung bagi sekolah-sekolah reguler yang menyelenggarakan pendidikan inklusif, baik secara teknis (operasional) maupun konsultatif." Pusat sumber ini berfungsi sebagai pusat pendidikan dan layanan kepada siswa
$\mathrm{ABK}$, pusat asesmen, penyediaan sumber belajar, pusat penyediaan alat bantu belajar dan mengajar serta pusat penelitian dan pengembangan. Salah satu tugasnya adalah menghadirkan GPK profesional sebagai guru kunjung. Guru ini akan membantu guru di sekolah reguler untuk memberikan pendidikan kepada siswa ABK. Pusat sumber juga bertugas untuk memberikan media belajar yang diperlukan, memberikan pelatihan tertentu bagi GPK sekolah reguler, maupun orang tua. Untuk memberikan dukungan kepada sekolah reguler, diperlukan satu atau dua pusat sumber untuk setiap kota/kabupaten. Pusat sumber ini dapat berupa lembaga baru atau pengembangan peran dan fungsi SLB. Idealnya memang sebuah pusat sumber memiliki bangunan sendiri yang dibentuk oleh pemerintah atau masyarakat dengan managemen yang dikelola sendiri, serta sekolah umum sebagai pusat sumber. Dalam kasus di Indonesia, banyak daerah yang menggunakan SLB sebagai pusat sumber untuk mempercepat keberadaanya serta untuk efektifitas.

Di Salatiga, Pokja inklusif rupanya ingin membuat UPTD pusat sumber berupa Klinik Konseling, bukan bekerjasama dengan SLB sebagai pusat sumber. Menurut Subagya (2011:4) kelemahan UPTD pusat sumber ini diantaranya adalah mahalnya proses pembentukannya, pendiriannya memerlukan proses yang lama. Sedangkan keuntungan dari SLB sebagai pusat sumber adalah memiliki tenaga terdidik untuk melayani $\mathrm{ABK}$, memiliki sarpras, alat media untuk ABK. Dalam kasusnya di Salatiga, strategi pusat sumber ini penulis anggap kurang efektif karena kelemahan yang dimiliki UPTD pusat sumber seperti dijelaskan di atas, yaitu memakan waktu yang cukup lama. Keberadaan pusat sumber ini baru diwujudkan pada tahun keempat dari pencanangan, yang dirasa cukup terlambat. Sehingga pelaksanaan program inklusi di Salatiga ini dalam jangka waktu 2012-2016 dianggap jalan ditempat.

Seperti yang dilakukan oleh Kota Sidoarjo sebagai salah satu kota yang bagus dan memiliki perkembangan yang cepat dalam 
menyelenggarakan program inklusi, 3 SLB ditunjuk untuk menjadi Pusat Sumber, yaitu SLBN Gedangan, SLB DWP Sidoarjo, dan SLB Veteran Wonoayu. Pusat Sumber ini menyediakan informasi bagi para sekolah mengenai hal teknis, dan diproyeksikan untuk deteksi dini dan penyelenggaran pendidikan transisi (Sulistyadi, 2014:5).

Selain birokrasi, faktor politik lain yang juga berpengaruh adalah adanya Agenda politik yang berbeda. Seperti yang telah dijelaskan sebelumnya, Klinik Konseling merupakan program inovasi yang diunggulkan oleh Dinas Pendidikan. Hal ini agak rancu karena klinik tersebut merupakan hasil dari program inklusi yang ditangani oleh Pokja Inklusi dimana (harusnya) terdapat beberapa dinas lain yang terlibat. Kurang terlibatnya dinas-dinas lain dalam pelaksanaan program ini bisa membuat Klinik Konseling "dipunyai" oleh Dinas Pendidikan. Walaupun memang Dinas Pendidikan berperan utama dalam program ini.

\section{Sumber Daya dalam Implementasi Kebijakan Pendidikan Inklusi di Kota Salatiga}

Dari sisi sumber daya, kualitas GPK menjadi keprihatinan tersendiri dalam implementasi kebijakan pendidikan inklusi di Kota Salatiga. GPK memiliki peran penting bagi keberhasilan pendidikan inklusif di sekolah karena GPK terlibat langsung dan berhadapan dengan siswa ABK. Pemenuhan GPK dalam program inklusi merupakan masalah yang umum terjadi (bandingkan Sulasmono dan Zanuet Indah, 2015; Dwi Sartika dan Bambang Ismanto, 2016; Sulasmono dan Tri Sulistyowati, 2016; Widyawati, 2017).

Idealnya menurut Subagya (2011:9) GPK seharusnya bukan guru kelas, bukan guru mata pelajaran, bukan guru pembimbing dan penyuluhan, melainkan "guru yang memiliki kualifikasi/ latar belakang pendidikan luar biasa yang bertugas menjembatani kesulitan ABK dan guru kelas/ mapel dalam proses pembelajaran serta melakukan tugas khusus yang tidak dilakukan oleh guru pada umumnya. Tugas khusus itu adalah tugas yang berkaitan dengan kebutuhan khusus ABK". Sedangkan untuk memenuhi persyaratan ideal tersebut pada prakteknya di sekolah umum merupakan hal yang sangat sulit. Selain karena minimnya sumber daya yang ada, dana juga masalah lain yang akan muncul. Sehingga dalam kebijakan disebutkan bahwa selain guru yang berlatar belakang PLB, GPK bisa berasal dari guru yang diberi pelatihan. Guru-guru tersebut merupakan guru kelas, guru mata pelajaran atau guru BK yang sudah ada di sekolah itu sebelumnya. Sehingga persoalan yang muncul lainnya adalah keterbatasan waktu yang dimiliki para GPK untuk membina siswa ABK disamping peran utamanya di sekolah tersebut sebagai guru utama. Kasus ini ditemui hampir disemua sekolah inklusi di Salatiga. Selain itu penelitian lain oleh Zakia (2015:114-115) di sekolahsekolah inklusi di Kabupaten Sukaharjo juga menemukan hal yang serupa, yaitu "GPK masih bertugas seperti guru pada umumnya yaitu berdiri di kelas dan mengajar anak-anak berkebutuhan khusus. GPK ini mengajar layaknya guru kelas dan bahkan ada juga yang menjadi guru kelas karena permasalahan kekurangan guru yang dialami pihak sekolah." Selain itu, pelatihan yang kurang memadai dalam membentuk GPK dari guru kelas/guru mata pelajaran/guru BK sebelum program inklusi dijalankan, membuat GPK sulit menjalankan fungsinya karena karena kurangnya kompetensi yang dimiliki.

Dilema yang muncul adalah jika GPK berasal dari GPK khusus yang berlatar PLB. Dana merupakan persoalan yang utama, karena pembiayaan inklusi tidak dapat diambilkan dari dana BOS, sehingga sekolah harus mengupayakan sendiri untuk hal ini. Sekolahsekolah swasta tidak mengalamami kesulitan dalam hal ini. Shadow teacher untuk siswa yang memerlukan dampingan biasanya didanai oleh orang tua siswa yang bersangkutan. Sedangkan siswa ABK di sekolah negeri biasanya memiliki latar belakang ekonomi lemah yang tidak memungkinkan melakukan hal yang serupa. Konsep shadow teacher ini belum 
menjadi pilihan bagi sekolah negeri inklusi di Salatiga.

Dengan diterapkannya konsep GPK yang berasal dari guru kelas, guru mata pelajaran dan guru BK maka adanya pelatihan yang intensif secara terjadwal dan berkala sangat penting. Berdasarkan data yang ada, pelatihan hanya dilakukan pada tahun 2012,2013 dan 2016 ketika terdapat dana dari APBN melalui Dirjen PKLK. Ketika dana tersebut tidak turun pada 2014 dan 2015 maka tidak diadakan peningkatan kapasitas oleh Pokja bagi GPK. Sebenarnya dengan dialokasikannya program inklusi dalam APBD Kota Salatiga merupakan suatu langkah besar, karena hal ini menunjukkan komitmen pemerintah dalam penyelenggaraan program. Namun alokasi anggaran sebagian besar masih digunakan untuk honor GPK, bukan untuk peningkatan kompetensi SDM. Walaupun honor tidak kalah penting, namun jika hal ini tidak dibarengi oleh upaya peningkatan profesionalisme GPK, maka kualitas pendidikan inklusif sulit untuk berkembang.

Gambaran di atas membenarkan Nagakaki (2013:3) bahwa salah satu faktor kesenjangan implementasi adalah faktor ekonomi. Biaya implementasi suatu aturan memang mahal, namun yang lebih penting bukan jumlahnya namun bagaimana sumber daya tersebut dialokasikan. Sehingga dibutuhkan asesmen kebutuhan dan pengalokasian anggaran yang sangat tepat sehingga anggaran yang ada bisa digunakan secara efisien dan tepat sasaran.

Dalam penelitian yang dilakukan oleh Haryono (2015:124) tentang program inklusi di Jawa Tengah, komponen utama yang menjadi prioritas terselenggaranya program inklusi adalah pembiayaan dan infrastruktur. Dalam temuannya didapat bahwa sarana dan prasarana untuk membantu proses belajar dan pengembangan bakat dan minat masih disamakan dengan siswa normal. Aksesibilitas di sekolah-sekolah inklusi di Salatiga juga masih diupayakan untuk dikembangkan. Aksesibilitas diartikan sebagai lingkungan dan fasilitas yang mudah dan sebaiknya tersedia bagi siswa terutama bagi siswa berkebutuhan khusus, misalnya jalan di lingkungan sekolah atau toilet yang bisa digunakan oleh anak yang berkursi roda. Sekolah-sekolah inklusi di Salatiga hampir semua tidak memiliki ruang sumber karena terkendala masalah pendanaan. Padahal menurut Saepul (2013:23-24).dalam pengembangan untuk mencapai standar, sekolah perlu memperhatikan faktor keamanan, kenyamanan dan kemudahan bagi yang menggunakannya.

\section{Disposisi dalam Implementasi Kebijakan Pendidikan Inklusi di Kota Salatiga}

Evaluasi terhadap disposisi para pelaksanaan menunjukkan hasil yang baik. Satu hal yang masih perlu dibahasa disini adalah peran Kepala sekolah. Peran Kepala Sekolah sangat penting bagi keberhasilan program inklusi di tingkat sekolah. Dibutuhkan komitmen Kepala Sekolah yang tinggi sehingga dapat mengeluarkan kebijakan-kebijakan tingkat sekolah yang membuat lingkungan ramah terhadap inklusi. Diharapkan para kepala sekolah mendayagunakan potensi yang ada.

Managemen Berbasis Sekolah memberi keleluasaan pada Kepala Sekolah untuk merencanakan, mengorganisasikan, mengarahkan, mengkoordinasikan, mengawasi, dan mengevaluasi komponen-komponen pendidikan dalam sekolah agar pendidikan inklusif berjalan optimal. Kepala Sekolah juga diharapkan pro-aktif dalam mensosialisasikan program ini ke masyarakat, mencari adanya ABK di lingkungan sekitar, ataupun mencari bantuan dari masyarakat untuk mendukung program di sekolah.

Hal ini sejalan dengan penelitian Yuliastutik (2011) yang menemukan bahwa pemimpin pembelajaran sekolah inklusif idelanya memiliki sifat "familiar, low profile, bijaksana, suportif, humoris, penuh kasih dan peduli dan menjaga keterlibatan para orang tua siswa, pemerintah, dan PT dalam pengembangan profesional guru”. Dia juga memberi saran agar Dirjen PMPTK dan Kepala P4TK mengembangkan pendidikan dan 
pelatihan kepala sekolah inklusif, khususnya bidang kepemimpinan pembelajaran serta Kepala Dinas Pendidikan dan Pengawas membuat sosialisasi pendidikan inklusif secara intens, memilih kepala sekolah yang mengerti manajemen pembelajaran sekolah inklusif.

Hal itu juga sejalan dengan testimoni Septin Pujiati, salah satu GPK yang mendapat beasiswa PLB di Universitas Negeri Surabaya, yang menyatakan bahwa ketika sedang praktek di beberapa sekolah inklusi di Surabaya, sekolah yang maju program inklusinya memiliki Kepala Sekolah yang kreatif, inisiatif dan aktif serta tidak menunggu bantuan dan perintah dari Dinas/Pokja saja. Hal inilah yang belum terjadi di Salatiga. Selama ini pihak sekolah hanya mengandalkan apa yang diperintah dan diberi oleh Dinas. Memang diperlukan pelaksana kebijakan yang memiliki semangat dalam menjalankan program ini, bukan hanya "robot" yang melaksanakan apa yang diperintah dan berhenti ketika perintah dihentikan.

Selain itu Kepala Sekolah juga harus berperan sebagai manager, motivator dan teladan bagi warga sekolah untuk bagaimana seharusnya memperlakukan dan melayani siswa ABK. Sebagai manager, Kepala Sekolah sebaiknya membuat program di sekolah terkait inklusi baik fisik berupa bangunan, media pembelajaran dan lainnya serta non fisik, yaitu menyiapkan mental warga sekolah agar menerima keberadaan siswa ABK dan sosialisasi kepada masyarakat. Peran Kepala Sekolah sebagai motivator untuk menumbuhkan kesadaran warga masyarakat juga penting. Program inklusi di sekolah ini dilakukan secara bertahap sesuai kemampuan dan kesiapan pihak sekolah.

Selain komitmen dari pihak sekolah, dibutuhkan juga komitmen dari Pokja Inklusi selaku pelaksana kebijakan dengan melakukan tugas dan fungsinya, salah satunya melaksanakan monitoring dan evaluasi. Evaluasi sangat penting peranannya dalam managemen yaitu untuk mengetahui ketercapaian dan efektifitas program. Sehingga dapat diketahui keberhasilan dan kekurangan serta hal-hal yang tidak berjalan sebagaimana mestinya. Sehingga dapat diketahui apa yang harus diperbaiki dan ditingkatkan, diteruskan ataupun dihentikan pelaksanannya. Belum adanya evaluasi yang terstruktur pada program ini membuat Pokja sulit untuk melihat perkembangan implementasi program ini di lapangan dan memperbaiki kekurangan yang ada pada program. Evaluasi program idealnya dilakukan rutin secara periodik, pertahun atau per empat tahun bergantung pada desain atau rencana yang telah dibuat sebelumnya.

\section{SIMPULAN DAN SARAN \\ Simpulan}

Program inklusi sejalan dengan kebutuhan masyarakat dunia pendidikan yang ada di Salatiga. Implementasi kebijakan program inklusi di Salatiga ini dinilai baik, yaitu dengan pencapaian $65 \%$. Komunikasi merupakan aspek yang paling lemah, ditandai dengan kurangnya komunikasi antar pelaksana kebijakan dan komunikasi kepada kelompok sasaran, dan kurang jelasnya informasi yang diterima. Struktur birokrasi masih kurang baik dilihat dari adanya panduan (SOP) dari Pemerintah Pusat namun masih terdapat fragmentasi dalamstruktur birokrasi ketika Kementerian Agama dan SLB belum aktif terlibat dalam program. Penilaian yang baik terdapat pada aspek sumber daya, ditandai dengan jumlah GPK yang sudah melebihi standar yang ditetapkan; SDM memiliki latar belakang PLB atau sudah mendapatkan pelatihan khusus; GPK ditunjang oleh fasilitas yang dinilai cukup baik; anggaran berasal dari APBN, APBD Provinsi dan APBD Kota walaupun belum ada partisipasi masyarakat berupa bantuan sosial. Terbatasnya waktu GPK untuk mengajar ABK karena GPK merangkap sebagai guru kelas, guru mata pelajaran atau guru BK; dan lemahnya pusat data dan informasi (Padati) ABK yang valid dan reliable menjadi poin yang kurang baik. Disposisi pelaksananprogram ini juga masih ada aspek yang kurang baik, dilihat dari GPK yang berstatus sebagai PNS belum mendapatkan angka kredit yang berguna untuk kenaikan 
Evaluasi Implementasi Kebijakan Pendidikan Inklusi | Sasadara Wahyu L., dkk.

jabatan/golongan dan selama program berjalan selama 4 tahun belum ada penghargaan yang diberikan kepada pelaksana kebijakan yang berperan penting dalam perkembangan pendidikan inklusi di Kota Salatiga, namun sudah terdapat komitmen sekolah untuk menyelenggarakan program inklusi dan tersedia honor untuk GPK.

\section{Saran}

Penulis memberikan beberapa saran agar penyelenggaraan program inklusi dapat terlaksana lebih baik lagi ke depannya. Bagi Pemerintah (Pokja Inklusi) diharapkan membentuk dan mengaktifkan saluran komunikasi antar GPK berupa KKG/MGMP; membuat komunikasi dengan lembaga lain dalam Pokja, yaitu Kementrian Agama dan SLB untuk menjangkau sekolah berbasis agama dan mengembangkan pusat sumber; menjalin kerjasama dengan DUDI untuk membuat kebijakan pro ABK, penyaluran lulusan, dan mengembangkan program inklusi melalui dana CSR; melakukan pelatihan yang intensif secara bergantian bagi para GPK; memperkuat sistem pendataan sekolah inklusi (Padati); melaksanakan monitoring dan evaluasi secara berkala; melakukan sosialisasi kepada masyarakat luas melalui brosur/leaflet tentang pendidikan inklusi yang tersimpan/tersebar di sekolah, kantor pemerintahan dll serta memasang spanduk/banner di sekolah atau area publik tentang pendidikan inklusi. Sedangkan bagi sekolah, antara lain Kepala Sekolah menciptakan LIRP (Lingkungan Inklusi Ramah pembelajaran); membuat managemen waktu yang efektif untuk pembelajaran ABK dengan GPK; Kepala sekolah lebih aktif dan memiliki inisiatif dalam mengembangkan program Inklusi di sekolah masing-masing; memberikan motivasi kepada guru untuk memberikan pelayanan yang bagus dan ikhlas bagi ABK serta kepada murid untuk menerima perbedaan yang ada. Secara bertahap membangun lingkungan fisik yang aksesibel untuk siswa ABK, menyediakan ruang sumber dan memenuhi sarana dan media pembelajaran sesuai kebutuhan ABK.

\section{DAFTAR PUSTAKA}

Edward III, George C. 1980. Implementing Public Policy. USA: Congresssional Quarterly Inc.

Sartika, Dwi dan Ismanto, Bambang. 2016. Evaluasi Penyelenggaraan Program Pendidikan Inklusif di Kota Palangkaraya. Jurnal Kelola 3 (1): 4966.

Haryono, A. S. 2015. Evaluasi Pendidikan Inklusi bagi Anak ABK di Provinsi Jawa Tengah. Jurnal Penelitian Pendidikan. 32 (2):119-126.

Nakagaki, M. 2013. Closing the Implementation Gap. CIPE Economic Reform, June (15): 1-8.

Nugroho, Riant. 2009. Public Policy. Jakarta: Elex Media Komputindo

Permendiknas Nomor 70 Tahun 2009 tentang Pendidikan Inklusi Bagi Peserta Didik Yang Memiliki Kelainan Dan Memiliki Potensi Kecerdasan Dan/Atau Bakat Istimewa

Sunaryo. 2009. Manajemen Pendidikan Inklusi.

Diakses pada 1 Agustus 2016 dari http://file.upi.edu/Direktori/FIP/JUR._ PEND._LUAR_BIASA/195607221985 031-SUNARYO/Makalah_Inklusi.pdf

Santrock, W. John. 2014. Psikologi Pendidikan. Edisi 5-Buku 1. Jakarta: Salemba Humanika

Stufflebeam D.L. dan Anthony J. Shinkfield (1985). Systematic Evaluation: A SelfInstructional Guide to Theory and Practice (Evaluation in Education and Human Services) 1985th Edition. Boston : Kluwer-Nijhoff

Subagya. 2011. Pusat Sumber, Pendidikan Khusus Dan Peran Dan Tugas Guru Pembimbing Khusus (GPK) disampaikan pada Workshop Pendidikan Inklusi tanggal 18 Januari 2011 di FKIP UNS Surakarta

Sulasmono, B.S. dan Yanuet Indah Z.T. 2015. Evaluation of Inclusive Education Program for Slow Learners in SD Negeri Pulutan 02 Salatiga. International Seminar "Quality 
Assurance For Education Proceeding.

Yogyakarta: UST Sarjanawiyata.

Sulasmono, B.S. dan Tri Sulistyowati. 2016. Context, Input, Process and Product Evaluation of the Inclusive Education Program in Public Elementary School. ICERI 2016 Proceeding. Yogyakarta: Universitas Negeri Yogyakarta.

Supriyanto, Tedjo. 2013. Salatiga Menyambut Sekolah Inklusi. Majalah Hatti Beriman, 07 (04)

Wahab, S. A. 2015. Analisis Kebijakan: Dari Formulasi ke Penyusunan ModelModel Implementasi Kebijak an Publik. Jakarta: Bumi Aksara.

Walker, Jo. th. Equal Right, Equal Opprtunity. Inclusive Education For Children With Disabilities. Global Campaign for Education, Handicap International.

Widodo, J. 2011. Analisis Kebijakan Publik. Malang: Bayumedia.

Widyawati, R. 2017. Evaluasi Pelaksanaan Program Inklusi Sekolah Dasar. Jurnal Kelola 4 (1): 109-120

Winarno, Budi. 2011. Kebijakan Publik (Teori Proses, dan Studi Kasus). Yogyakarta: CAPS

Wulan, Dwi Kencana. 2011. Peran Pemahaman Karakteristik Siswa Cerdas Istimewa Berbakat Istimewa (Cibi) Dalam Merencanakan Proses Belajar Yang Efektif Dan Sesuai Kebutuhan Siswa. Humaniora 2 (1): 269-276

Yuastutik, Ida. 2011. Kepemimpinan Pembelajaran Kepala Sekolah Inklusi: Studi Multikasus Tiga Sekolah Inklusi di Kota Malang. Disertasi, Program Studi Manajemen Pendidikan, Program Pascasarjana, Universitas Negeri Malang. Diakses pada 30 Maret 2017 dari http://karyailmiah.um.ac.id/index.php/disertasi/arti cle/view/11266

Zakia, Dieni L. 2015). Guru Pembimbing Khusus (Gpk): Pilar Pendidikan Inklusi. Prosiding Seminar Nasional Pendidikan "Meretas Sukses Publikasi Ilmiah Bidang Pendidikan Jurnal Bereputasi” Kerjasama Program Studi
S-3 Ilmu Pendidikan Program Studi S-2 Pendidikan Luar Biasa Universitas Sebelas Maret Surakarta dan ISPI Wilayah Jawa Tengah. Surakarta. .Salatiga Miliki Unit Layanan Konsultasi Pendidikan. (2013, Desember 2). Wawasan , p. 23. 